\title{
The Determinants of Small and Medium-sized Enterprises Performance in Nigeria
}

\author{
Idris Isyaku Abdullahi ${ }^{1,2}$, Chindo Sulaiman ${ }^{2,3, *}$ \\ ${ }^{1}$ Accounting and Finance Technology Programme, Abubakar Tafawa Balewa University, Bauchi, Nigeria
${ }^{2}$ Department of Economics, Faculty of Economics and Management, University Putra Malaysia, Malaysia
Department of Economics, Faculty of Social and Management Sciences, Bauchi State University Gadau, Nigeria
}

Copyright (C) 2015 Horizon Research Publishing All rights reserved.

\begin{abstract}
This study aimed at examining the determinants of small and medium-sized enterprises (SMEs) performance in Nigeria. An autoregressive distributed lag approach to cointegration was applied to sample from 1981 to 2010 to achieve the set objective. The results revealed that both in the short-and long-run, interest rate and net export have had a negative impact on SMEs performance. At the same time, other determinants such as government spending, political instability and level of education were found to have insignificant impact during the studied period. Therefore, maintenance of low interest rate will undoubtedly assist to boost the performance of SMEs in Nigeria. As such, monetary authorities need to play a very important role toward achieving the target.
\end{abstract}

Keywords SMEs, Interest Rate, Net Export, ARDL Approach

\section{Introduction}

Small and medium-sized enterprises (SMEs) play critical role in the development of private sector of every nation. In addition, with increased globalization, SMEs have an important role to play as their products are opened to the international market. Furthermore, they compete with foreign multi-national corporations as competitors in the domestic markets. There are certain merits and demerits for SMEs participation in global markets. These include, from the merits side, the flexibility and rapid response to changes due to their smallness nature. From the demerits side, it includes SMEs size which hinders them to favourably compete in the global markets. The sub- sector assisted greatly in the area of employment generation, provision of goods and services as well as the general improvement in GDP [1]. Though, in spite of the tremendous role the sub sector is said to play in developing countries for their sustainable development, much need to be done considering the fact that SMEs still performed far below expectation [2]. Some of the factors that inhibit the speedy development of SMEs include unfavorable economic conditions, under capitalization resulting from lack of access to credit from Banks and non-Banks financial institutions, dilapidated situation of infrastructures, high operating cost and corruption to mention but a few [3]. SMEs constitute a larger proportion of the entire businesses in both developed and developing countries. For instance, SMEs represents 95 percent of the entire businesses in United Kingdom and contributed over 65 percent of the labour force. SMEs contribution to GDP in UK stood at 30 percent [4]. Similarly, in Nigeria it was revealed that about 97 percent of the entire enterprises constitute the SMEs and their employment of labour was put at 50 percent with contribution to country's industrial output at 50 percent [5]. However, with globalization process, some specific factors which range from entrepreneurial, external and internal determine the success of SMEs in developing countries. The aim of this study is to determine the impact of these factors identified by literatures on the SMEs performance in Nigeria. Specifically, the study examines the determinants of SMEs performance capturing both domestic and global markets. These determinants include: the interest rate, political instability, government spending on SMEs, net export and level of education. Whilst, the SMEs performance will be captured using share of SMEs contribution to GDP.

The findings of this study would have some practical significance. For instance, for policy makers, it will assist them to ascertain the real performance driven-factors for SMEs, which will greatly facilitate good policy formulating process. Similarly, for entrepreneurs, the outcome of the study will enhance their understanding of SMEs performance determining factors and hence adjusting business decisions in the right direction to facilitate their business performance.

The study has been organized as follows. Section 1 is the introduction, which presents the background of the study. Section 2 is the literature review, which gives the summary of studies conducted in related area. Section 3 is the 
methodology, where the data and method of analysis are presented. Results and discussions are reported in section 4 . While, conclusions and policy recommendations are presented in section 5 .

\section{Brief Literature Review}

Looking at the role played by SMEs in development and employment creation, it is imperative to understand the determinants of SMEs performance and its failure. Al-Mahrouq [6] asserted that such an investigation is crucial for the developing countries as the findings could be useful for entrepreneurs and planners of the relevant countries. The success factors which are termed "critical success factors" have developed by Rockart [7]. The identified factors vary from country to country in their effectiveness due to the geographical, economic and cultural differences. Some of these factors have been tested to have contributed to success of SMEs in various countries. Example of these studies include: Pesanen [8], Rose et al. [9] in Malaysia, April [10] in Namibia, Ahmad [11] in Australia and Malaysia, Al Mahrauq [6] in Jordan. Moreover, the successes of SMEs resulting from globalization are attributed to some critical factors identified by literatures. Reuber and Fischer [12] opined that obtaining sales outside own local markets is an objective of many SMEs. The related literatures emphasized on strong management team/leadership as reported by Ghosh et al. [13] and Wijewardena and Zoysa [14]. Other literatures stressed on entrepreneurship [15-16], product quality [14] and use of internet [17]. Additionally, certain external factors have been identified as success determining factors for SMEs as pointed out by Feindt et al. [18]. One of the critical external success factors is government support programs [9].

Based on the above literatures, this study employed an econometric technique to examine the determinants SMEs performance in Nigeria. The approach is different and also the variables to be used quite differ from most previous studies.

\section{Methodology and Data}

The study adopts the production function similar to new growth model. The model showing a relationship between government policies and growth of small industry in Nigeria is developed following the work of Ogunleye and Obiora [19]. This model is a modified production function and this is complimented by a series of selected variables usually introduced in the growth models, the growth of the small scale industry is specified to depend on government spending on SMEs, political instability, interest rate, net export, level of educational development and so on. However, to avoid inclusion of too many variables into the model which could lead to econometrically potential specification error, this would concentrate on only the afore-listed variables. As such, the model is specified as follows:

$$
\begin{aligned}
& \ln S G D P_{t}=\eta_{0}+\eta_{1} \ln I N T_{t}+ \\
& +\eta_{2} P I_{t}+\eta_{3} \ln G O V_{t}+\eta_{4} \ln N E X_{t}+ \\
& +\eta_{5} \ln L E D_{t}+\psi_{t}
\end{aligned}
$$

where SGDP is small and medium scale enterprises share of GDP, INT is the interest rate, PI is political instability proxied by a dummy, GOV is government spending on SMEs, NEX is net export, LED is level of education proxied by adult literacy and $\psi_{t}$ is the error term.

There are also exogenous factors that affect the performance of these Small Sale Enterprises [20]. These include the issue of whether the industrialization policy of an economy promotes large-sale or small-scale production, the level of support from government, i.e. government policy intervention, the availability of credits, and the existence of an effective demand. The real success of any SMEs depends on the skills, capabilities and abilities of entrepreneurs to innovate and take risks in the presence of various uncertainties. However, entrepreneurial initiatives can be constrained by the government regulations as well as by a limited demand by consumers for local products and services. The unfavorable macroeconomic environment has also been identified as one of the major constraints to the operation of small scale businesses. There are various special credit schemes open to SMEs with minimal interest rate. However, the rate of interest has influence on the entrepreneurs' willingness to allow external participation, since they fear to lose control over their business. Consequently, interest on credit to small scale industries is a major determinant of the survival of the small scale industry.

\subsection{Sources of Data}

The research work relies on secondary sources of data which comprises of data from National Bureau of Statistics of Nigeria and Central Bank of Nigeria. Data on share of SMEs contribution to GDP and government spending on SMEs were obtained from National Bureau of Statistics database. While, data on interest rate, net export and level of education were sourced from central bank of Nigeria (CBN) database.

\subsection{Technique of Estimation}

The technique of estimation to be used in this study would be autoregressive distributed lag (ARDL) approach to cointegration developed by Pesaran et al. [21]. The methodology has been chosen owing to its unique characteristics which make it more suitable than other methods that could be used to achieve similar objective. Unlike other methodologies for testing cointegration relationship, ARDL could be applied irrespective of the order of integration of the variables, i.e., whether the variables are I(0), I(1) or mixed. Secondly, with ARDL, both long-and short-run estimates could be obtained simultaneously. Thirdly, it is suitable technique for both 
large sample and small sample size between 30 to 80 observations.

The specification of ARDL begins with constructing conditional error correction model as thus:

$$
\begin{aligned}
& \Delta \ln S G D P_{t}=\phi_{0}+\sum_{i=1}^{l} \rho_{i} \Delta \ln S G D P_{t-i} \\
& +\sum_{i=0}^{l} \delta_{i} \Delta \ln I N T_{t-i}+\sum_{i=0}^{l} \gamma_{i} \Delta \ln G O V_{t-i} \\
& +\sum_{i=0}^{l} \vartheta_{i} \Delta \ln N E X_{t-i}+\sum_{i=0}^{l} \chi_{i} \Delta \ln L E D_{t-i} \\
& +\alpha_{1} \ln S G D P_{t-1}+\alpha_{2} \ln I N T_{t-1} \\
& +\alpha_{3} P I_{t-1}+\alpha_{4} \ln G O V_{t-1} \\
& +\alpha_{5} \ln N E X_{t-1}+\alpha_{6} \ln L E D_{t-1}+\xi_{t}
\end{aligned}
$$

$\ln S G D P_{t}=\phi_{1}+\sum_{i=1}^{l} \rho_{1 i} \ln S G D P_{t-i}+\sum_{i=0}^{l} \delta_{1 i} \ln I N T_{t-i}+\sum_{i=0}^{l} \theta_{1 i} P I_{t-i}+\sum_{i=0}^{l} \gamma_{1 i} \ln G O V_{t-i}+\sum_{i=0}^{l} \vartheta_{1 i} \ln N E X_{t-i}$ $+\sum_{i=0}^{l} \chi_{1 i} \ln L E D_{t-i}+\varepsilon_{1 t}$

Similarly, the short-run model of the error correction specification would be estimated to ascertain the short-run dynamic behavior of the variables in the model.

$$
\begin{gathered}
\Delta \ln S G D P_{t}=\phi_{2}+\sum_{i=1}^{l} \rho_{2 i} \Delta \ln S G D P_{t-i}+\sum_{i=0}^{l} \delta_{2 i} \Delta \ln I N T_{t-i}+\sum_{i=0}^{l} \theta_{2 i} P I_{t-i}+\sum_{i=0}^{l} \gamma_{2 i} \Delta \ln G O V_{t-i} \\
+\sum_{i=0}^{l} \vartheta_{2 i} \Delta \ln N E X_{t-i}+\sum_{i=0}^{l} \chi_{2 i} \Delta \ln L E D_{t-i}+\beta E C M_{t-1}+\varepsilon_{2 t} \\
E C M=\ln S G D P_{t}-\phi_{1}-\sum_{i=1}^{l} \rho_{1 i} \ln S G D P_{t-i}-\sum_{i=0}^{l} \delta_{1 i} \ln I N T_{t-i}-\sum_{i=0}^{l} \theta_{1 i} P I_{t-i}-\sum_{i=0}^{l} \gamma_{1 i} \ln G O V_{t-i} \\
-\sum_{i=0}^{l} \vartheta_{1 i} \ln N E X_{t-i}-\sum_{i=0}^{l} \chi_{1 i} \ln L E D_{t-i}
\end{gathered}
$$

\begin{tabular}{|c|c|c|c|c|c|c|c|c|}
\hline \multirow{3}{*}{ Variable } & \multicolumn{4}{|c|}{ ADF Test Statistics } & \multicolumn{4}{|c|}{ PP Test Statistics } \\
\hline & \multicolumn{2}{|c|}{ Constant } & \multicolumn{2}{|c|}{ Trend } & \multicolumn{2}{|c|}{ Constant } & \multicolumn{2}{|c|}{ Trend } \\
\hline & Level & $\begin{array}{c}\text { First } \\
\text { Difference }\end{array}$ & Level & $\begin{array}{c}\text { First } \\
\text { Difference }\end{array}$ & Level & $\begin{array}{c}\text { First } \\
\text { Difference }\end{array}$ & Level & $\begin{array}{c}\text { First } \\
\text { Difference }\end{array}$ \\
\hline $\ln S G D P$ & $\begin{array}{l}-0.455 \\
(0.886)\end{array}$ & $\begin{array}{c}-6.133 \\
(0.000)^{* * *}\end{array}$ & $\begin{array}{l}-2.558 \\
(0.300)\end{array}$ & $\begin{array}{c}-2.979 \\
(0.157)\end{array}$ & $\begin{array}{l}-0.399 \\
(0.897)\end{array}$ & $\begin{array}{c}-6.313 \\
(0.000) * * *\end{array}$ & $\begin{array}{l}-2.617 \\
(0.276)\end{array}$ & $\begin{array}{c}-6.377 \\
(0.000)^{* * * *}\end{array}$ \\
\hline $\ln I N T$ & $\begin{array}{l}-2.166 \\
(0.223)\end{array}$ & $\begin{array}{c}-8.231 \\
(0.000)^{* * *}\end{array}$ & $\begin{array}{l}-2.495 \\
(0.328)\end{array}$ & $\begin{array}{c}-8.665 \\
(0.000)^{* * *}\end{array}$ & $\begin{array}{c}-2.889 \\
(0.059)^{*}\end{array}$ & $\begin{array}{c}-7.903 \\
(0.000) * * *\end{array}$ & $\begin{array}{l}-2.422 \\
(0.361)\end{array}$ & $\begin{array}{c}-8.778 \\
(0.000)^{* * *}\end{array}$ \\
\hline $\ln L E D$ & $\begin{array}{c}2.700 \\
(1.000) \\
\end{array}$ & $\begin{array}{c}-4.676 \\
(0.000)^{* * *}\end{array}$ & $\begin{array}{c}-1.921 \\
(0.618)\end{array}$ & $\begin{array}{c}-4.857 \\
(0.003)^{* * *}\end{array}$ & $\begin{array}{c}3.108 \\
(1.000) \\
\end{array}$ & $\begin{array}{c}-4.651 \\
(0.000)^{* * *}\end{array}$ & $\begin{array}{l}-1.736 \\
(0.709) \\
\end{array}$ & $\begin{array}{c}-6.339 \\
(0.000)^{* * * *}\end{array}$ \\
\hline $\ln N E X$ & $\begin{array}{c}-3.324 \\
(0.023)^{* *}\end{array}$ & $\begin{array}{c}-5.666 \\
(0.000)^{* * *}\end{array}$ & $\begin{array}{c}-4.879 \\
(0.003)^{* * *}\end{array}$ & $\begin{array}{c}-5.609 \\
(0.000) * * *\end{array}$ & $\begin{array}{c}-3.268 \\
(0.026)^{* *}\end{array}$ & $\begin{array}{c}-12.180 \\
(0.000) * * *\end{array}$ & $\begin{array}{c}-7.845 \\
(0.000) * * *\end{array}$ & $\begin{array}{c}-15.393 \\
(0.000)^{* * *}\end{array}$ \\
\hline $\ln G O V$ & $\begin{array}{l}-0.896 \\
(0.775)\end{array}$ & $\begin{array}{c}-4.045 \\
(0.004)^{* * *}\end{array}$ & $\begin{array}{c}-4.653 \\
(0.006)^{* * *}\end{array}$ & $\begin{array}{c}-4.135 \\
(0.015)^{* *}\end{array}$ & $\begin{array}{l}-1.255 \\
(0.636)\end{array}$ & $\begin{array}{c}-4.090 \\
(0.004) * * *\end{array}$ & $\begin{array}{l}-1.696 \\
(0.727)\end{array}$ & $\begin{array}{c}-4.120 \\
(0.016) * *\end{array}$ \\
\hline
\end{tabular}

where $E C M$ is the error correction term and $\beta$ is the coefficient of the error correction term which measures the speed of adjustment of the variables back to equilibrium in the long-run. It also shows the percentage of deviation from the equilibrium that needs to be corrected.

Table 1. Unit root test using augmented Dickey Fuller (ADF) and Phillips Perron (PP)

$* * *, * *, *$ Denotes $1 \%, 5 \%$ and $10 \%$ significance level respectively. 


\section{Results and Discussions}

Prior to estimating cointegration, the study employed popular unit root tests, augmented Dickey Fuller test and Phillips Perron to identify the order of integration of the variables under consideration. Though ARDL approach does not formally requires pretesting for unit root but it is worthy to note that any presence of I(2) among the variables may render the methodology invalid. This is because, the methodology has been developed based on the assumption that the variables are either purely $\mathrm{I}(0), \mathrm{I}(1)$ or mixed. Therefore, we conducted the unit root tests to be sure of the variables' order of integration and the results are reported in Table 1 . The results reveal that $\ln N E X$ is stationary at level, whereas $\ln S G D P, \ln I N T, \ln L E D$ and $\ln G O V$ are stationary at first difference. Having mixture of the order of integration, ARDL approach becomes the most suitable method to apply in this case. Therefore, the results justified the application of ARDL framework.

Having established the suitability of the method based on the unit root test results, cointegration test was conducted using OLS to check if the variables have long-run relationship or not. To accomplish this task, an optimum lag of 3 was selected based on schwarz information criterion (SIC) and the null hypothesis of no cointegration $\left(H_{0}: \alpha_{1}=\alpha_{2}=\alpha_{3}=\alpha_{4}=\alpha_{5}=\alpha_{6}=0\right)$ was tested against the alternative hypothesis $\left(H_{a}: \alpha_{1} \neq \alpha_{2} \neq \alpha_{3} \neq \alpha_{4} \neq \alpha_{5} \neq \alpha_{6} \neq 0\right)$. The results reported in Table 2 indicate that the computed F-statistic, 4.889, is greater than the upper bound value, 4.608 , at $5 \%$ significance level of the Narayan [22] Table. This shows presence of long-run relationship among our variables and therefore we could safely reject our null hypothesis.

Table 2. Cointegration Test Results

\begin{tabular}{cccccc}
\hline Model & & & & \multicolumn{2}{c}{$\begin{array}{c}\text { Critical } \\
\text { Bounds Test }\end{array}$} \\
\cline { 2 - 6 } & Lag & F-stats & $\begin{array}{c}\text { Significance } \\
\text { Level }\end{array}$ & $\begin{array}{c}\text { Unrestricted } \\
\text { intercept and } \\
\text { no trend }\end{array}$ \\
\hline$\left(\ln S G D P_{t} / /\right.$ & 3 & $\mathbf{4 . 8 8 9}$ & & $\mathrm{I}(0)$ & $\mathrm{I}(1)$ \\
$\ln I N T_{t}, P I_{t} \ln G O V_{t}$, & & & & & \\
$\left.\ln N E X_{t}, \ln L E D_{t}\right)$ & & & & & \\
& & & $1 \%$ & 4.537 & 6.370 \\
& & & $\mathbf{5 \%}$ & $\mathbf{3 . 1 2 5}$ & $\mathbf{4 . 6 0 8}$ \\
& & & $10 \%$ & 2.578 & 3.858 \\
\hline
\end{tabular}

Critical values are obtained from Narayan table case III, Narayan (2005). The boldness indicates the level of significance at which the F-statistic exceeds the upper bound.

Next step was the estimation of long-run model to obtain the long-run coefficients of the relationship between the SMEs performance and its determinants. The results presented in Table 3 denote that interest rate and net export have significant negative impact on SMEs performance. This indicates that as interest rate decreases, the SMEs performance increases. It suggests that as interest rate falls, more entrepreneurs are able to borrow from the banks to finance their businesses. Consequently, the act helps their businesses to thrive. The net export shows significant negative impact on SMEs performance. It reveals that when net export increases, the performance of SMEs reduces. This may sound counter-intuitive but the findings may not be unconnected with the consistent fall in the value of Nigeria's currency relative to foreign currencies (particularly US\$) over the years. Furthermore, most of the SMEs in Nigeria do not use recent technology that could aid their international transactions in the digital world. Consequently, this hinders their goods to be widely advertised and purchased on the global market. On the other hand, government spending, level of education and political instability do not have significant impact on the performance of SMEs during the study period.

Table 3. Estimated long run coefficients' results.

\begin{tabular}{|c|c|c|}
\hline \multicolumn{3}{|c|}{ Dependent Variable, $\ln S G D P_{t}$} \\
\hline Regressors & Coefficients & T-statistics ( $p$-value) \\
\hline $\ln I N T_{t}$ & -1.363 & $\begin{array}{c}-1.769 \\
(0.096)^{*}\end{array}$ \\
\hline $\ln G O V_{t}$ & 0.953 & $\begin{array}{c}1.531 \\
(0.145) \\
\end{array}$ \\
\hline $\ln N E X_{t}$ & -0.490 & $\begin{array}{c}-2.127 \\
(0.049)^{* *}\end{array}$ \\
\hline $\ln L E D_{t}$ & -0.043 & $\begin{array}{l}-0.105 \\
(0.918) \\
\end{array}$ \\
\hline$P I_{t}$ & -0.362 & $\begin{array}{l}-0.417 \\
(0.682)\end{array}$ \\
\hline Constant & -2.204 & $\begin{array}{l}-0.767 \\
(0.454)\end{array}$ \\
\hline
\end{tabular}

******* Denotes $1 \%, 5 \%$ and $10 \%$ significance level respectively. PSP is a dummy variable representing political instability.

Table 4. Short-run ARDL result.

\begin{tabular}{|c|c|c|}
\hline \multicolumn{3}{|c|}{ Dependent Variable, $\Delta \ln S G D P_{t}$} \\
\hline Regressors & Coefficients & T-statistics ( $p$-value) \\
\hline$\Delta \ln I N T_{t}$ & -0.302 & $\begin{array}{c}-1.904 \\
(0.073)^{*}\end{array}$ \\
\hline$\Delta \ln G O V_{t}$ & -0.158 & $\begin{array}{l}-1.391 \\
(0.181)\end{array}$ \\
\hline$\Delta \ln N E X_{t}$ & -0.028 & $\begin{array}{c}-2.183 \\
(0.042)^{* *}\end{array}$ \\
\hline$\Delta \ln N E X_{t-1}$ & 0.028 & $\begin{array}{c}2.055 \\
(0.055)^{*} \\
\end{array}$ \\
\hline$\Delta \ln N E X_{t-2}$ & 0.016 & $\begin{array}{c}1.729 \\
(0.101)\end{array}$ \\
\hline$\Delta \ln L E D_{t}$ & -0.010 & $\begin{array}{l}-0.106 \\
(0.917)\end{array}$ \\
\hline$P I_{t}$ & -0.080 & $\begin{array}{l}-0.486 \\
(0.633)\end{array}$ \\
\hline Constant & -0.488 & $\begin{array}{l}-0.905 \\
(0.377)\end{array}$ \\
\hline$E C M_{t-1}$ & -0.221 & $\begin{array}{c}-2.163 \\
(0.044)^{* *}\end{array}$ \\
\hline $\mathrm{R}^{2}$ & 0.775 & \\
\hline Adjusted $\mathrm{R}^{2}$ & 0.635 & \\
\hline F-stat. $(8,18)$ & $6.906(0.000)^{* * *}$ & \\
\hline DW-stat. & 2.207 & \\
\hline
\end{tabular}

***,**,* Denotes $1 \%, 5 \%$ and $10 \%$ significance level respectively. PSP is a dummy variable representing political instability.

The short-run results presented in Table 4 indicate that interest rate has negative and significant impact on SMEs development. It means that even in the short-run, a rise in the interest rate leads to fall in SMEs performance. Furthermore, 
net export has significant negative impact on SMEs performance. This is as a result of consistent loss of value in the Nigeria's currency relative to foreign currency over the years. On the other hand, level of education and political instability were found to be insignificant in influencing the performance of SMEs. The error correction term depicts $22 \%$ speed of adjustment to the long-run equilibrium. Being negative, less than one and significant, the coefficient of the error term confirms the cointegration relationship among the variables. The measures of the goodness fit of the model reported in Table 4 which included $\mathrm{R}^{2}$, F-statistics and DW-statistic were all in favour of the model's good fit.

Ensuring the reliability and efficiency of the estimates, the study conducted some diagnostic tests and reported the results in Table 5. The results reveal that the model passed serial correlation, normality and heteroscedasticity tests as we could not reject their null hypotheses. Conversely, we were able to reject the null hypothesis of the functional form test at $1 \%$ significant level which indicates presence of functional form problem. Furthermore, as recommended by Pesaran and Pesaran [23], the study employed the cusum and cusumSQ tests for stability of the model along the sampled periods. The plots illustrated in Figure $1 \& 2$ show that the residuals lie within the critical bounds at $5 \%$ level of significance, which connotes the stability of the model.

Table 5. Diagnostic Test

\begin{tabular}{|c|r|r|}
\hline Test Statistics & LM Version & \multicolumn{1}{|c|}{ F Version } \\
\hline $\begin{array}{c}\text { A: Serial } \\
\text { Correlation }\end{array}$ & $\begin{array}{r}\text { CHSQ }(1)=0.491 \\
(0.483)\end{array}$ & $\begin{array}{r}\mathrm{F}(1,15)=0.278 \\
(0.606)\end{array}$ \\
\hline B: Functional Form & $\begin{array}{r}\mathrm{CHSQ}(1)=16.888 \\
(0.000)^{* * *}\end{array}$ & $\begin{array}{r}\mathrm{F}(1,15)=25.050 \\
(0.000)^{* * *}\end{array}$ \\
\hline C: Normality & $\begin{array}{r}\text { CHSQ }(1)=5.071 \\
(0.079)^{*}\end{array}$ & $\begin{array}{r}\text { Not applicable } \\
\text { D: }\end{array}$ \\
$\begin{array}{c}\text { CHSQ }(1)=1.908 \\
(0.167)\end{array}$ & $\begin{array}{r}\mathrm{F}(1,25)=1.901 \\
(0.180)\end{array}$ \\
\hline
\end{tabular}

***,**,* Denotes $1 \%, 5 \%$ and $10 \%$ significance level respectively. A:Langrange multiplier test of residual serial correlation

B: Ramsey's RESET test using the square of the fitted values $\mathrm{C}$ :Based on a test of skewness and kurtosis of residuals

D: Based on the regression of squared residuals on squared fitted values

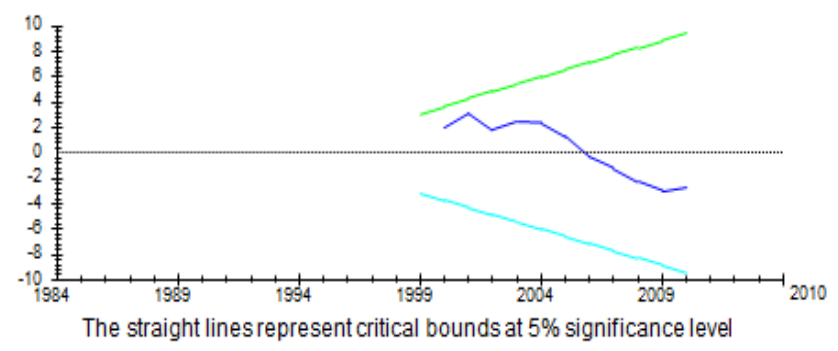

Figure 1. Plot of cumulative sum of recursive residuals

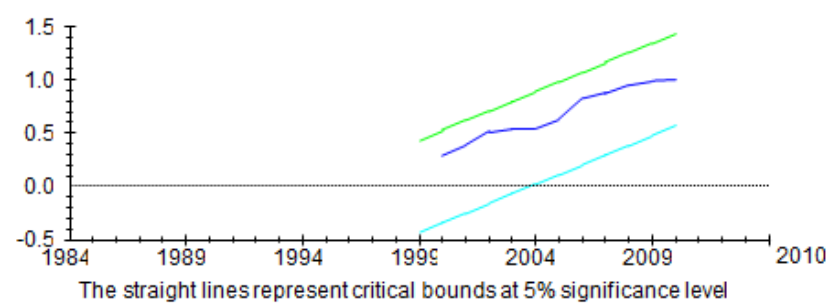

Figure 2. Plot of cumulative sum of squares of recursive residuals

\section{Conclusions and Recommendations}

The study sought to examine the impact of interest rate, government spending, net export, level of education and political instability on the SMEs performance in Nigeria. To achieve the task, we applied ARDL approach to cointegration based on the sampled period of 1981-2010. The results indicated that both in the long-and short-run, interest rate and net export have had significant negative impact on SMEs performance. That is, these two factors were the main determinants of SMEs performance within the study period. Other determinants included in the model, government spending, level of education and political instability, were insignificant in determining SMEs performance. That is, they were ineffective in influencing the performance of SMEs in Nigeria. The diagnostic tests suggested that the model's estimates were reliable and efficient as the model passed the major tests. The cusum and cusumSQ tests also indicated the model was stabled along the sampled periods.

Recommendation from this study, suggests that, for Nigeria to enhance SMEs performance, interest rate should be maintained relatively low. This will enable the entrepreneurs to access loans in order to expand their businesses. Moreover, maintenance of low interest rate will attract the new enterers into the entrepreneurship circle to source loans and start- up businesses. This in turn will assist in facilitating SMEs performance and thereby improving economic growth. As such, a policy targeting interest rate stabilization needs to be prioritized to boost SMEs performance in Nigeria. In addition, policies toward stabilization of the country's currency should also be accorded importance. This will enable SMEs to gain more revenue from sales abroad and subsequently boost their performance. Similarly, Information Technology (IT) and internet literacy within SMEs should be taken into account by the firms as it will greatly assist in making their goods to be more competitive and acceptable in the global markets, hence improving their performance.

\section{REFERENCES}

[1] Ihua, U. B. (2009). SMEs key failure-factors: a comparison between the United Kingdom and Nigeria. Journal of Social Sciences, 18(3), 199-207. 
[2] Arinaitwe, S. K. (2006). Factors constraining the growth and survival of small scale businesses: A developing countries analysis. Journal of American academy of Business, Cambridge, 8(2), 167-179.

[3] Oboh, G. (2002). Bank participation in the promotion of small and medium scale enterprises. Being a paper presented at the $6^{\text {th }}$ fellows and associates forum of CIBN on $13^{\text {th }}$ April.

[4] Day, J. (2000). The value and importance of the small firm to the world economy. European Journal of marketing, 1033-1037.

[5] Ariyo, D. (1999). Small firms are the backbone of the Nigerian economy. Africa Economic analysis, Africa business information services, Bridgnorth United Kingdom.

[6] Al-Mahrouq, M. (2010). Success Factors of Small and Medium Enterprises: The Case of Jordan. Zagreb International Review of Economics and Business, 13(2), 89-106.

[7] Rockart, J. F. (1978). Chief executives define their own data needs. Harvard business review, 57(2), 81-93.

[8] Pasanen, M. (2003). Multiple entrepreneurship among successful SMEs in peripheral locations. Journal of Small Business and Enterprise Development, 10 I ( 4), .418 - 425.

[9] Rose, R. C., Kumar, N., \& Yen, L. L. (2006). The dynamics of entrepreneurs' success factors in influencing venture growth. Journal of Asia Entrepreneurship and Sustainability, 2(2), 1-22.

[10] April,W. I. (2005). Critical factors that influence the success and failure of SMEs in Namibia in the Khomas Region. Doctoral dissertation, Stellenbosch: University of Stellenbosch.

[11] Ahmad, N. H., and Seet, P. S. (2009). Dissecting behaviours associated with business failure: a qualitative study of SME owners in Malaysia and Australia. Asian Social Science, 5(9), 98.

[12] Reuber, R. and Eileen Fischer (1997). The Influence of the Management Team's International Experience on the Internationalization Behaviors of SMEs. Journal of International Business Studies, 28 (4), 807-825.
[13] Ghosh, B. C., Liang, T. W., Meng, T. T., \& Chan, B. (2001). The Key Success Factors, Distinctive Capabilities, and Strategic Thrusts of top SMEs in Singapore. Journal of Business Research, 51(3), 209-221.

[14] Wijewardena, H, and De Zoysa, A., (2005). A Factor Analytic Study of the Determinants of Success in Manufacturing SMEs. 35th EISB Conference-Sustaining the Entrepreneurial Spirit over Time, Barcelona, Spain, 12-14 September, 2005.

[15] Knight, G. (2000). Entrepreneurship and Marketing Strategy: The SME under Globalization. Journal of International Marketing, 8 (2), 12-32.

[16] Benzing, C., Chu, H.M., and Kara, O. (2009). Entrepreneurs in Turkey: a factor analysis of motivations, success factors, and problems. Journal of Small Business Management, 47(1), 58-91.

[17] Chittithaworn, C., Islam, M. A., Keawchana, T., and Yusuf, D. H. M. (2011). Factors affecting business success of small \& medium enterprises (SMEs) in Thailand. Asian Social Science, 7(5), 180-190.

[18] Feindt, S., Jeffcoate, J., and Chappell, C. (2002). Identifying success factors for rapid growth in SME e-commerce. Small Business Economics, 19(1), 51-62.

[19] Ogunleye, E.K. and Obiora I.K. (2007). Structural Economy Reform and Performance in the Manufacturing Sector: Selected Paper for the 2007 Annual Conference.

[20] Iniodu, P.U. and Udomesiet. C. U. (2004). Commercial Banking System Efficiency and Financing of Small Scale Enterprises (SSEs) in the 21 st century. Egwakhide F. et al. eds, Leading issues in Macroeconomics Management and Development. Nigeria Economic Society, Ibadan.

[21] Pesaran, M. H., Shin, Y., \& Smith, R. J. (2001). Bounds testing approaches to the analysis of level relationships. Journal of Applied Econometrics, 16(3), 289-326.

[22] Narayan, P. K., \& Narayan, S. (2005). Estimating income and price elasticities of imports for Fiji in a cointegration framework. Economic Modelling, 22(3), 423-438.

[23] Pesaran, H. M. and Pesaran, B. (1997). Microfit 4.0. Oxford University Press, Oxford. 